\title{
Weed Flora of Cherry, Walnut, Apple, Almond and Pear Orchards in Northwestern Marmara Region of Turkey
}

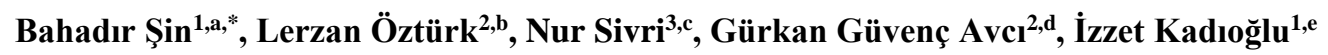

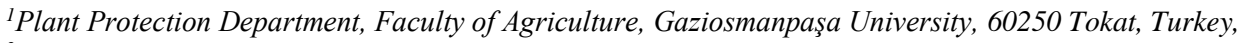 \\ ${ }^{2}$ Viticulture Research Institute, 59100 Süleymanpaşa/Tekirdağ, Turkey, \\ ${ }^{3}$ Plant Protection Department, Faculty of Agriculture, Namık Kemal University, 59100 Tekirdağ, Turkey,
}

*Corresponding author

\begin{tabular}{|c|c|}
\hline A R T ICLE INFO & A B S T R A C T \\
\hline $\begin{array}{l}\text { Keywords: } \\
\text { Northwestern Marmara Region } \\
\text { Orchards } \\
\text { Weeds } \\
\text { Flora } \\
\text { Turkey }\end{array}$ & $\begin{array}{l}\text { A study covering cherry, walnut, apple, almond and pear orchards in Edirne, Kirklareli and Tekirdağ } \\
\text { provinces was carried out in } 2015-2018 \text { with the aim of determination of weed flora, weed } \\
\text { frequencies and densities. Total of } 64 \text { species belonging to } 30 \text { families were identified in fruit tree } \\
\text { orchards. Among all the families the most members were in Asteraceae } 13 \text { species, Poaceae, } 11 \\
\text { species, Brassicaceae } 5 \text { species and Lamiaceae } 3 \text { species families. The dominant weed species were } \\
\text { Amaranthus retroflexus L., Polygonum aviculare L., Capsella-bursa pastoris L. (Medik)., } \\
\text { Concolvulus arvensis L., Lepidium draba L., Raphanus raphanistrum L., Chenopodium album L., } \\
\text { Cichorium intybus L. in Tekirdağ while Datura stramonium L. distribution in Edirne Uzunköprü } \\
\text { and Kurklareli was remarkably high. Semi parazitic weed Viscum album and full parasite Cuscuta } \\
\text { campestris Yunck were also detected in some orchards. V. album was widespread among pear trees } \\
\text { while Cuscuta campestris Yunck was detected only in suckers emerged in apple and cherry orchards. } \\
\text { According to density } \text { A. retroflexus has received the first order with } 76 \text { plant } / \mathrm{m}^{2}, \text { following } \text { C. album } \\
\text { with } 54 \text { plant } / \mathrm{m}^{2}, \text { Lactuca serriola with } 27 \text { plant } / \mathrm{m}^{2}, \text { D. stramonium } \mathrm{L} \text {. with } 24 \text { plant } / \mathrm{m}^{2}, \text { Portulaca } \\
\text { oleracea } \text { with } 21 \text { plant } / \mathrm{m}^{2}\end{array}$ \\
\hline
\end{tabular}

Türk Tarım - Gıda Bilim ve Teknoloji Dergisi 7(12): 2252-2258, 2019

\section{Kuzey Marmara Bölgesi (Türkiye) Kiraz, Ceviz, Elma, Badem ve Armut Bahçelerinde Yabancı Ot Florası}

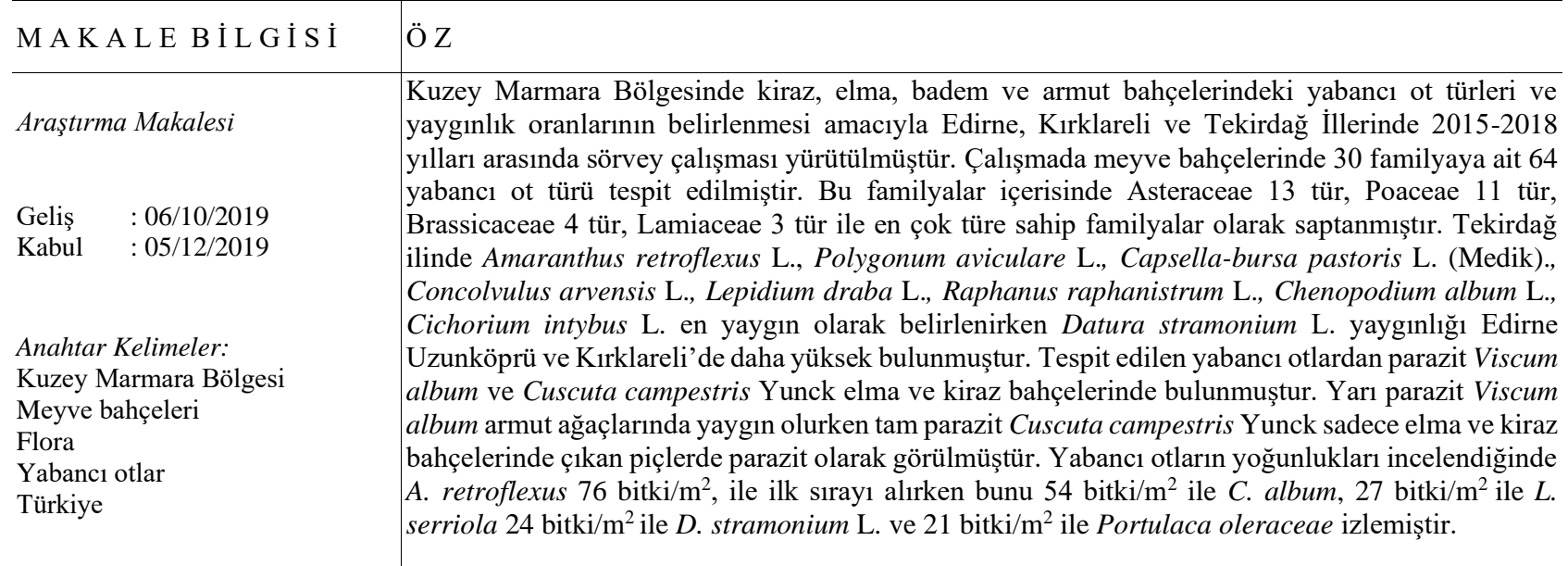




\section{Introduction}

Many factors affect plant growth and weeds are considered as one of the most important. Weeds compete with plants for water and nutrients, which are essential resources for plant growth. The weed infestation is more problematic in newly established orchards because young trees are more susceptible to weed competition due to slowly growth and less developed root system. In contrast with denser developed root systems weeds can reach deeper soil depths, uptake minerals and water, grow faster than crop plants and reduce the amount of sunlight that can reach to young plants. Weeds also reduces areea that plants require for growth (Wisler and Norris, 2005).

Weed infestation is problem in Turkey due to high humidity and high temperature characteristics. Variations in weed species and population densities have been observed every year depending on several factors such as climate, cultural practices and cropping system. Dense weed infestations complicate harvesting and other agricultural practices. Tillage and herbicide applications are done to control weeds. But both operations increase crop production expenditure. Besides tillage is short lived and carries a risk of tree root and trunk damage during tilling by tractor mounted tillers. On the other hand herbicides are selective and each herbicide controls certain weeds. Additionally the competition of weed species varies depending on factors such as growth period. Grass weeds retain more water than broadleaf weeds during growing period (Nasr et al., 2013). Thus precautions on control of grass weeds must be taken in dry soil conditions in summer. Therefore, knowledge of the type of weed species present in the agricultural area is essential for effective herbicide application and weed management.

Several researchers carried out studies in apple and pear orchards in Central Anatolia and identified 82 and 59 species respectively (Eşitmez and Işık, 2016; Yazlık and Tepe, 2001). However weed flora of orchards in Northwestern Marmara Region is little known and there is no current record on presence of weed species. On this purpose we carried out a study in Edirne, Kirklareli and Tekirdağ Provinces of Northwestern Marmara Region in order to determine weed species coinfecting apple, pear, walnut, almond and cherry orchards.

\section{Material and Method}

A survey covering fruit tree growing areas was carried out in 2015-2018. In order to determine all species orchards were visited regularly four times (winter: February; spring: mid April - mid May; summer: mid June - mid July; autumn: mid September - mid October) a year. Orchard visits were conducted in Tekirdağ Province Şarköy, Malkara and Süleymanpaşa districts; Edirne Province Keşan and Uzunköprü districts; Kırklareli Province Merkez district. Provinces were selected based on production data of Turkish Statistical Institute and sampled orchards were selected randomly (Table 1).

During visits presence or absence of weed species was recorded for each orchard. Weed samples were collected, put separately in a nylon bag and transferred to Tekirdağ Viticulture Research Institute for further systematic research. In addition weed density was evaluated by counting plants or shoots of weeds at $1 \mathrm{~m}^{2}$ frame. A quadrate of size $1 \mathrm{~m} \mathrm{x} 1 \mathrm{~m}$ was thrown five times in each orchard and then averages count were used to determine number of weeds in $\mathrm{m}^{2}$. Frequency of occurrence (f\%) of species was calculated as the number of orchards where the species was recorded divided by the total number of orchards visited (Odum, 1971; Sirma et al., 2001). In addition blooming periods of each weed species were observed and recorded.

For species identification the herbarium of each species were prepared by slow drying of plant samples at room temperature. After complete drying each weed sample were sticked on to cardboard, covered by nylon and labelled. Collection site, province, collection date were recorded on each label. Weeds were identified by comparing plant morphology with published literatures of Yunker (1932), Royer and Dickson (1998), Dawson et al., (2019).

Table 1 Information about number of surveyed orchards

\begin{tabular}{|c|c|c|c|}
\hline & Edirne & Kirklareli & Tekirdağ \\
\hline Total number of orchards & 31 & 21 & 177 \\
\hline Walnut & 10 & 5 & 47 \\
\hline Pear & 7 & 7 & 34 \\
\hline Cherry & 4 & 2 & 58 \\
\hline Apple & 7 & 3 & 32 \\
\hline Almond & 3 & 4 & 6 \\
\hline Orchard size(da) & $1-50$ & $10-50$ & $1-70$ \\
\hline Minimum weather temperature & \multicolumn{3}{|c|}{$9.6^{\circ} \mathrm{C}$} \\
\hline Maximum weather temperature & \multicolumn{3}{|c|}{$30.7^{\circ} \mathrm{C}$} \\
\hline
\end{tabular}

\section{Results and Discussion}

After species identifications 64 species belonging to 30 families were recorded in pear, almond, cherry, apple and walnut orchards. Cherry and apple orchards included 61 species while pear, almond and walnut orchards had 58, 52 and 43 species respectively (Table 2, Figure 1). In survey area the predominance was shown by Asteraceae family having 13 species followed by Poaceae, Brasicaceae and Lamiaceae each having 11,5 and 3 species. As Euphorbiaceae, Plantaginaceae, Solanaceae, Geraniaceae and Apiaceae include 2 species the rest of families like Cucurbitaceae, Rubiaceae, contain only one species. Compared to other families Asteraceae (20.2\%), Poaceae $(17.3 \%)$ and Brassicaceae $(7.93 \%)$ showed higher relative frequencies.

The related researches were carried out in different parts of Turkey. In a research covering apple orchards in Kayseri 129 weed species belonged to 33 families consisted of 2 monocotyledonous and 31 dicotyledonous were identified. The species identified were mostly belonged to Asteraceae 21 species, Poaceae 15 species and Brassicaceae 13 species families (Eşitmez ve Işık, 2016). In another research in Van 59 weed species from 22 families and 82 species from 28 families were found in pear and apple orchards respectively (Yazlık and Tepe, 2001).

Dicotyledons comprise the highest proportion with 51 species $(81.2 \%)$, following monocotyledons with 12 species $(18.8 \%)$. Poaceae and Cyperaceae were the only monocotyledon families in research areas. The number of dicotyledon weeds in cherry, apple, pear, almond and walnut orchards were 59, 59, 52, 41 and 23 species respectively. Although all monocotyledons were observed in walnut orchards cherry, apple, pear and almond plantations contain only 11 species. 
Table 2 Botanical names, family, life form and presence of weeds species in orchards

\begin{tabular}{|c|c|c|c|c|c|c|c|c|}
\hline Family & Scientific name & Life form & Life span & $\mathrm{C}$ & $\mathrm{Ap}$ & $\mathrm{P}$ & $\mathrm{Al}$ & $\bar{W}$ \\
\hline Amaranthaceae & Amaranthus retroflexus L. & Th & $\mathrm{A}$ & + & + & + & + & + \\
\hline Aniaceoe & Bifora radians Bieb. & Th & A & - & + & - & - & - \\
\hline Ap1aceae & Conium maculatum L. & Th & $\mathrm{A} / \mathrm{Bi}$ & + & + & + & + & + \\
\hline \multirow{12}{*}{ Asteraceae } & Artemisia absinthium L. & $\mathrm{H}$ & $\mathrm{Bi}$ & - & + & - & - & - \\
\hline & Carduus nutans L. & $\mathrm{H}$ & $\mathrm{Bi}$ & + & + & + & + & + \\
\hline & Cirsium arvense $\mathrm{L}$. & $\mathrm{G}$ & $\mathrm{P}$ & + & + & + & + & - \\
\hline & Conyza canadesis $\mathrm{L}$. & Th & $\mathrm{A}$ & + & + & + & - & - \\
\hline & Cichorum intybus L. & $\mathrm{H}$ & $\mathrm{P}$ & + & + & + & - & - \\
\hline & Lactuca serriola $\mathrm{L}$. & $\mathrm{H}$ & $\mathrm{A} / \mathrm{Bi}$ & + & + & + & + & + \\
\hline & Senecio vulgaris L. & Th & A & + & + & + & + & + \\
\hline & Silybum marianum (L). Gaertn & $\mathrm{H}$ & $\mathrm{Bi}$ & + & + & + & + & - \\
\hline & Sonchus arvensis L. & Th & $\mathrm{P}$ & + & + & + & + & + \\
\hline & Taraxacum officinale F.H.Wigg. & $\mathrm{H}$ & $\mathrm{P}$ & + & + & + & + & - \\
\hline & Xanthium strumarium L. & $\mathrm{Ch}$ & A & + & + & + & + & + \\
\hline & Xanthium spinosum L. & Th & $\mathrm{A}$ & + & + & + & + & + \\
\hline Apocynaceae & Cynanchum acutum $\mathrm{L}$. & $\overline{\mathrm{Ch}}$ & $\mathrm{P}$ & + & + & + & + & + \\
\hline Boraginacea & Heliotropium europaeum $\mathrm{L}$. & Th & A & + & + & + & + & + \\
\hline \multirow{5}{*}{ Brassicaceae } & Capsella-bursa pastoris (L.) Medik. & Th & $\mathrm{A}$ & + & + & + & + & + \\
\hline & Lepidium draba $\mathrm{L}$. & $\mathrm{H}$ & A & + & + & + & + & + \\
\hline & Raphanus raphanistrum $\mathrm{L}$. & Th & A & + & + & + & + & + \\
\hline & Sinapis arvensis L. & Th & A & + & + & + & + & - \\
\hline & Sisymbrium altissium $\mathrm{L}$. & Th & A & + & + & + & - & + \\
\hline Caryophyllaceae & Stellaria media (L.) Will & Th & $\mathrm{A}$ & + & + & + & + & + \\
\hline Chenopodiaceae & Chenopodium album $\mathrm{L}$. & Th & A & + & + & + & + & + \\
\hline Convolvulaceae & Convolvulus arvensis L. & $\mathrm{H}$ & $\mathrm{P}$ & + & + & + & + & + \\
\hline Cucurbitaceae & Echballium elaterium L & $\mathrm{H}$ & $\mathrm{P}$ & + & + & + & + & + \\
\hline Cuscutaceae & Cuscuta capestris Yunck. & Th & A & + & + & - & - & - \\
\hline Cyperaceae & Cyperus rotundus $\mathrm{L}$. & $\mathrm{G}$ & $\mathrm{P}$ & + & + & + & + & + \\
\hline \multirow{2}{*}{ Euphorbiaceae } & Euphorbia helioscopia L. & Th & A & + & + & + & + & + \\
\hline & Mercurialis annua $\mathrm{L}$. & Th & A & + & + & + & + & + \\
\hline Fabaceae & Trifolium repens L. & Th & $\mathrm{P}$ & + & + & + & + & + \\
\hline \multirow{2}{*}{ Geraniaceae } & Geranium dissectum $\mathrm{L}$. & Th & A & + & + & + & + & - \\
\hline & Geranium molle L. & Th & A & + & + & + & + & - \\
\hline \multirow{3}{*}{ Lamiaceae } & Ballota nigra $\mathrm{L}$. & $\mathrm{H}$ & $\mathrm{P}$ & + & + & - & + & - \\
\hline & Lamium amplexicaule $\mathrm{L}$. & Th & A & + & + & + & + & - \\
\hline & Melisa officinalis L. & $\mathrm{H}$ & $\mathrm{P}$ & + & + & - & - & - \\
\hline Fumariaceae & Fumaria officinalis L. & Th & $\mathrm{A}$ & + & + & + & + & - \\
\hline Malvaceae & Malva neglecta Wallr. & Th & A & + & + & + & + & - \\
\hline Oxalidaceae & Oxalis corniculata $\mathrm{L}$. & $\mathrm{H}$ & $\mathrm{P}$ & + & + & + & - & + \\
\hline Papaveraceae & Papaver rhoeas $\mathrm{L}$. & Th & A & + & + & + & + & - \\
\hline \multirow{2}{*}{ Plantaginaceae } & Plantago lanceolata $\mathrm{L}$. & $\mathrm{H}$ & $\mathrm{P}$ & + & + & + & + & + \\
\hline & Plantago major L. & $\mathrm{H}$ & $\mathrm{A} / \mathrm{P}$ & + & + & + & + & + \\
\hline \multirow{11}{*}{ Poaceae } & Elymus repens (L.) Gould. & $\mathrm{H}$ & $\mathrm{A}$ & + & + & + & + & + \\
\hline & Alopecurus myosuroides Huds & $\mathrm{H}$ & A & + & + & + & + & + \\
\hline & Avena fatua $\mathrm{L}$. & Th & A & + & + & + & + & + \\
\hline & Bromus tectorum $\mathrm{L}$. & Th & A & + & + & + & + & + \\
\hline & Cynodon dactylon $\mathrm{L}$. & $\mathrm{G}$ & $\mathrm{A} / \mathrm{P}$ & + & + & + & + & + \\
\hline & Echinochloa crus-galli (L.) P. Beauv. & Th & A & + & + & + & + & + \\
\hline & Eleusine indica $(\mathrm{L})$.Gaertn. & Th & A & + & + & + & + & + \\
\hline & Lolium perenne $\mathrm{L}$. & $\mathrm{H}$ & $\mathrm{P}$ & - & - & - & - & + \\
\hline & Poa annua $\mathrm{L}$. & Th & A & + & + & + & + & + \\
\hline & Setaria viridis (L.) Beauv & Th & A & + & + & + & + & + \\
\hline & Sorghum halepense (L.) Pers. & $\mathrm{H}$ & A & + & + & + & + & + \\
\hline \multirow{2}{*}{ Polygonaceae } & Rumex crispus $\mathrm{L}$. & $\mathrm{H}$ & $\mathrm{P}$ & + & + & + & + & + \\
\hline & Polygonum aviculare L. & Th & A & + & + & + & + & + \\
\hline Portulacaceae & Portulaca oleacea $\mathrm{L}$. & Th & A & + & + & + & + & + \\
\hline Primulaceae & Anagallis arvensis (L.) U. Manns \& Anderb. & Th & A & + & + & + & + & - \\
\hline Rosaceae & Potentila reptans $\mathrm{L}$ & $\mathrm{H}$ & $\mathrm{A} / \mathrm{P}$ & + & - & - & - & + \\
\hline Rubiaceae & Galium aparine $\mathrm{L}$. & Th & A & + & + & + & - & - \\
\hline Santalaceae & Viscum album $\mathrm{L}$. & $\mathrm{Ph}$ & $\mathrm{P}$ & + & - & + & + & - \\
\hline Scrophulariaceae & Veronica hederifolia $\mathrm{L}$. & Th & A & + & + & + & + & - \\
\hline \multirow{2}{*}{ Solanaceae } & Datura stramonium L. & Th & $\mathrm{A}$ & + & + & + & - & + \\
\hline & Solanum nigrum L. & Th & $\mathrm{A} / \mathrm{P}$ & + & + & + & + & + \\
\hline Zygophyllaceae & Tribulus terrestris L. & Th & $\mathrm{A}$ & + & + & + & + & + \\
\hline
\end{tabular}

Th: Therophyte, G: Geophytes, H: Helophytes, Ch: Chamephyte, Ph: Phanerophyte, A: Annual, Bi: Biannual, P: Perannual, C: Cherry, Ap: Apple, P: Pear, Al: Almond, W: Walnut 


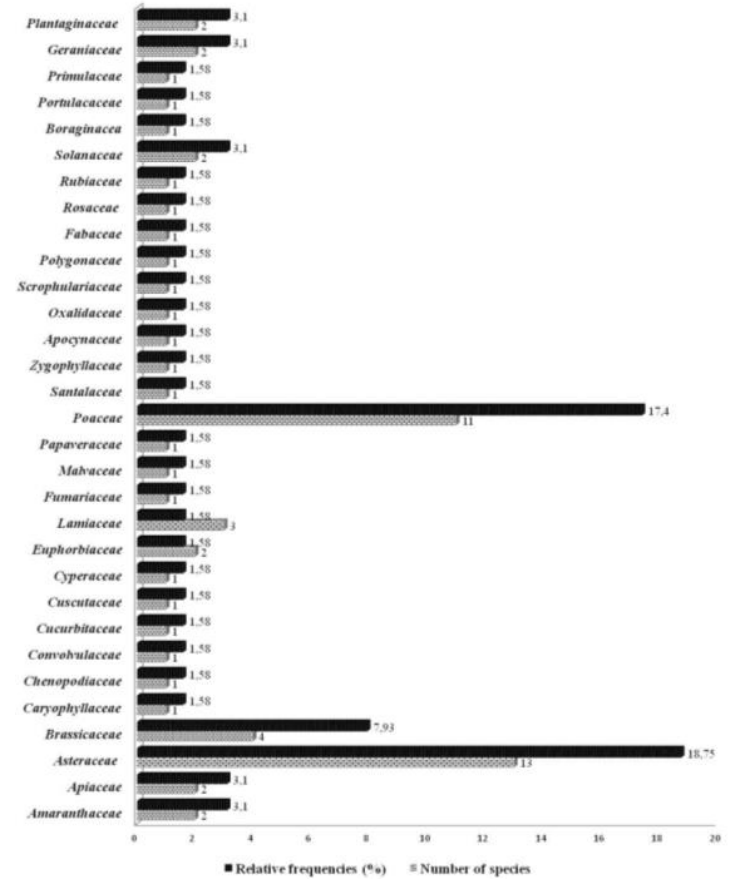

Figure 1 Relative frequencies of families and the number of species

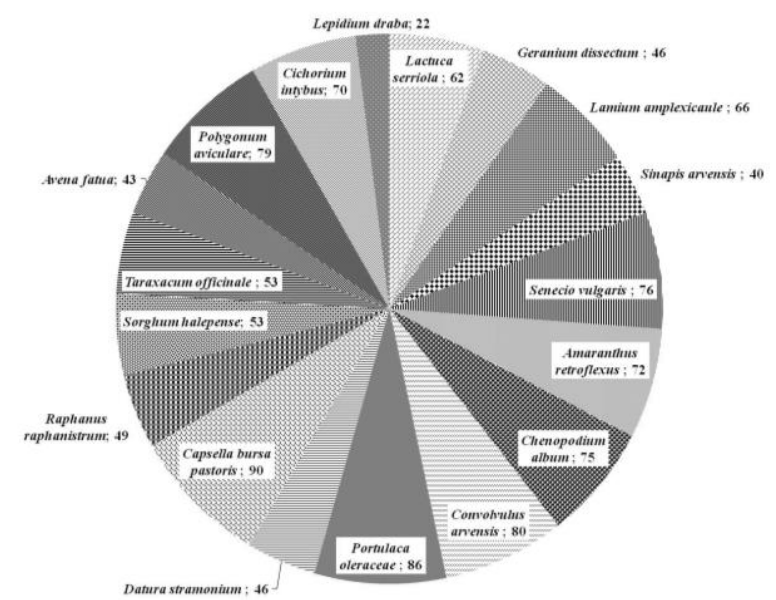

Figure 2 Frequency of distribution of some weed species in orchards

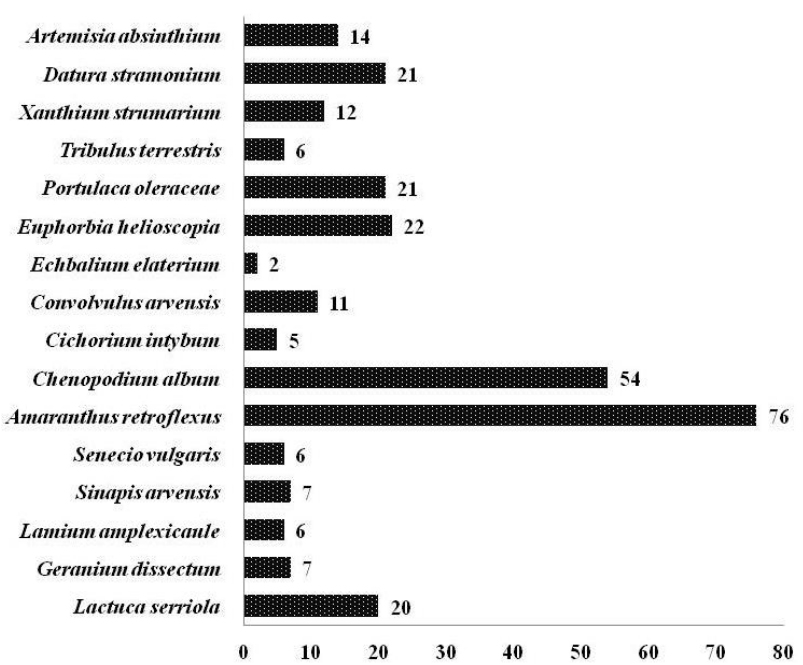

Figure 3 Average plant density of some weed species in study area $\left(\right.$ plant $\left./ \mathrm{m}^{2}\right)$
Dicotiledons are broad-leaved weeds with paired cotyledons. Out of 64 weeds recorded 52 were broad-leaved dicotyledons. The most frequently encountered species in cherry, apple, pear, almond and walnut orchards were Capsella bursa pastoris, Solanum nigrum, Convolvulus arvensis, Amaranthus retroflexus, Chenopodium album and Portulaca oleraceae occuring in up to $80 \%$ of sampled areas (Figure 2).

The predominant species present in visited orchards in Tekirdağ were Capsella bursa pastoris (93\%), Polygonum aviculare L. (86\%), Portulaca oleraceae L. (83\%) Cichorium intybus L. (80\%) following Convolvulus arvensis (82\%), Senecio vulgaris L. (81\%), Chenopodium album L. (76\%), Amaranthus retroflexus L. (76\%), Lactuca serriola L.(70\%), Raphanus raphanistrum L. (60\%), Lepidium draba L. (56\%), Sorghum halepense L. (44\%). In contrast Datura stramonium $(60 \%)$ was common in walnut growing areas. A. retroflexus can grow well in sandy, clay, loam soil types, has drought tolerance and is capable of producing over 200,000 seeds (Walsh, 1993; Stevens, 1957). C. album is highly adaptable to wide range of climate conditions and produce 200 and 20,000 seeds/plant (Korsmo et al., 1981; Ozer et al., 1998). In addition $S$. halepense is very competitive and adaptive to all kind of soil and climate conditions. With its self-compatible characteristic and seed longevity this weed can reproduce in any suitable condition and easily disperse. By rapid growing this weed directly shades newly planted rootstocks decreases nutrient and moisture availability to other plants (Holm et al., 1977). Besides S. halepense secrete some allelopathic compounds like dhurrin which has growth inhibition effect on other plants (Tesio and Ferrero, 2010).

Solanum nigrum, $C$. bursa pastoris require hot and longer daylight period but can grow in any type of soil. The soil and weather conditions of Northwestern Marmara Region is appropriate for growth of these species. On the other hand $P$. oleraceae likes more moist and fertile soils. Plants cannot grow healthy under dry conditions. According to our observations plenty of $P$. oleraceae plants were observed in most of irrigated orchards in both provinces.

Although D. stramonium was one of the predominant weed species in walnut orchards, it was not observed in any of the almond orchards. D. stramonium prefer arable and fertile soils. The weed distribution and population density were lowest in Tekirdağ due to unmanaged and non-tilled soils. On the contrary due to well managed-tilled soil and appropriate climate conditions in Kırklareli and Edirne $D$. stramonium was able to reproduce by several ways and disperse to new areas. The frequency of occurrence of this weed in Edirne province Uzunköprü district and Kırklareli province Kizılc1kdere village was estimated as $57 \%$ and $71 \%$ respectively. This weed has been reported as a weed in more than 40 crops in almost 100 countries (Holm et al., 1997). Approximately 56\% yield reduction effect of this weed on maize and cotton were reported in different countries (Witt and Luke, 2017).

The blooming period of these dicotyledons differ as well. Some species flower in summer months while others flower in spring, autumn and winter (Table 3).

The increase of weed density in irrigated and fertile orchards was significant whereas rare distribution of several species were observed in non tilled and non irrigated areas. Physical and chemical characteristics of soil, moisture content, cropping system, tillage type, environmental and climatic conditions, weed control practices found to influence weed distribution and population density. 
Table 3 Blooming period of broad leaved weed species

\begin{tabular}{|c|c|c|c|}
\hline Weed species & Bloom period & Weed species & Bloom period \\
\hline Amaranthus retroflexus $\mathrm{L}$. & July - Sept. & Malva neglecta Wallr. & June-Sept. \\
\hline Artemisia absinthium L. & July-Sept. & Melisa officinalis L. & June-Aug. \\
\hline Anagallis arvensis (L.) U. Manns \& Anderb. & Apr.-Aug. & Mercurialis annua $\mathrm{L}$. & July - Sept. \\
\hline Ballota nigra $\mathrm{L}$. & June-Oct. & Oxalis corniculata $\mathrm{L}$. & May-Aug \\
\hline Bifora radians L. Bieb & April-July & Papaver rhoeas $\mathrm{L}$. & May-Aug \\
\hline Capsella-bursa pastoris (L.) Medik. & April-May & Plantago lanceolata $\mathrm{L}$. & April- Sept. \\
\hline Carduus nutans L. & April-Aug. & Plantago major $\mathrm{L}$. & April- Sept. \\
\hline Chenopodium album $\mathrm{L}$. & June-Sept. & Polygonum aviculare L. & April-Oct. \\
\hline Cirsium arvense $\mathrm{L}$. & May-Sept. & Portulaca oleacea L. & June- Sept. \\
\hline Cichorum intybus L. & May-Aug. & Potentila reptans $\mathrm{L}$ & May-July \\
\hline Conium maculatum $\mathrm{L}$. & Apr.-July & Raphanus raphanistrum $\mathrm{L}$. & July-Aug. \\
\hline Convolvulus arvensis $\mathrm{L}$. & May-Sept. & Rumex crispus L. & Apr.-Sept. \\
\hline Conyza canadesis $\mathrm{L}$. & July-Sept. & Senecio vulgaris $\mathrm{L}$. & June-Aug. \\
\hline Cuscuta campestris L. & July-Sept & Silybum marianum (L).Gaertn & July-Aug. \\
\hline Cynanchum acutum $\mathrm{L}$. & May-Oct. & Sinapis arvensis $\mathrm{L}$. & March- Aug. \\
\hline Datura stramonium L. & July-Oct. & Sisymbrium altissium L. & April- Aug. \\
\hline Echballium elaterium $\mathrm{L}$ & April-Oct. & Solanum nigrum $\mathrm{L}$. & June- Sept. \\
\hline Euphorbia helioscopia L. & May-Aug. & Sonchus arvensis $\mathrm{L}$ & March-Aug. \\
\hline Fumaria officinalis L. & May- Aug. & Stellaria media (L.) Will. & Feb.-June \\
\hline Galium aparine $\mathrm{L}$. & May- July. & Taraxacum afficinale F.H.Wigg & Feb.- May \\
\hline Geranium dissectum $\mathrm{L}$. & May-Aug. & Trifolium repens $\mathrm{L}$. & March-July \\
\hline Geranium molle L. & May-Aug. & Tribulus terrestris L. & June-Nov. \\
\hline Heliotropium europaeum L. & June-Sept. & Viscum album $\mathrm{L}$. & March-May \\
\hline Lactuca serriola $\mathrm{L}$. & April-Aug. & Veronica hederifolia $\mathrm{L}$. & March-June \\
\hline Lamium amplexicaule L. & Apr.-Aug. & Xanthium strumarium L. & July-Sept. \\
\hline Lepidium draba $\mathrm{L}$. & Apr.-Aug. & & \\
\hline
\end{tabular}

Table 4 Booming period of narrow leaved weed species

\begin{tabular}{ll|ll}
\hline \multicolumn{1}{c|}{ Weed species } & \multicolumn{1}{c}{ Bloom period } & \multicolumn{1}{c}{ Weed species } & Bloom period \\
\hline Elymus repens (L.) Gould. & May-June. & Eleusine indica (L) Gaertn. & June-Sept. \\
Alopecurus myosuroides L. Huds. & May-June & Lolium perenne L. & May-July \\
Avena fatua L. & Apr.-May & Poa annua L. & March-April \\
Bromus tectorum L. & Apr.-June. & Setaria viridis (L.) Beauv. & June-Sept. \\
Cynodon dactylon L. & July-Oct. & Sorghum halepense (L.) Pers. & July-Dec. \\
Echinochloa crus-galli (L.) P. Beauv. & July-Oct. & Cyperus rotundus L. & July-Nov. \\
\hline
\end{tabular}

Table 5 Number of species in each life form associated with five fruit trees.

\begin{tabular}{l|ccccc}
\hline \multirow{2}{*}{ Life form } & \multicolumn{5}{c}{ Number of species } \\
\cline { 2 - 6 } & Cherry & Apple & Pear & Almond & Walnut \\
\hline Therophyte & 37 & 38 & 36 & 32 & 28 \\
Hemicryptophyte & 18 & 18 & 16 & 3 & 10 \\
Geophytes & 3 & 3 & 3 & 2 & 3 \\
Chamaephyte & 2 & 2 & 1 & 1 & 2 \\
Phanerophyte & 1 & 0 & 1 & 0 \\
\hline
\end{tabular}

Table 6 The floristic elements of weed species in survey areas

\begin{tabular}{l|cc}
\hline \multicolumn{1}{c|}{ Floristic elements } & Number of species & Percentage (\%) \\
\hline Cosmopolitan & 34 & 53.1 \\
Eur + Asian & 18 & 28.1 \\
Eur-Asia+North Africa & 7 & 10.9 \\
Europe & 1 & 1,58 \\
Medirerranean & 1 & 1.58 \\
North Africa & 1 & 1.58 \\
South America & 1 & 1.58 \\
North America & 1 & 1.58 \\
\hline
\end{tabular}




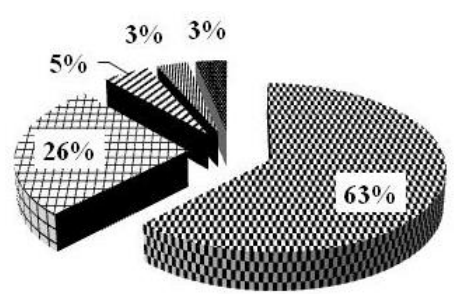

SAnnual

IPerannual

" Biannual

III Annual/Biannual

Annual/Perannual

Figure 4 The percentage of weed species in terms of life

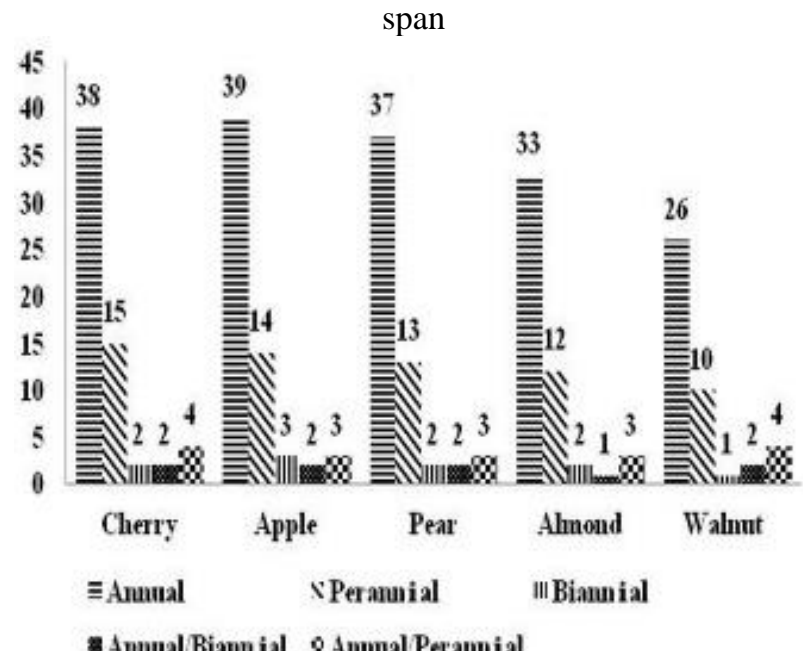

Figure 5 The number of weed species in each fruit tree in terms of life span
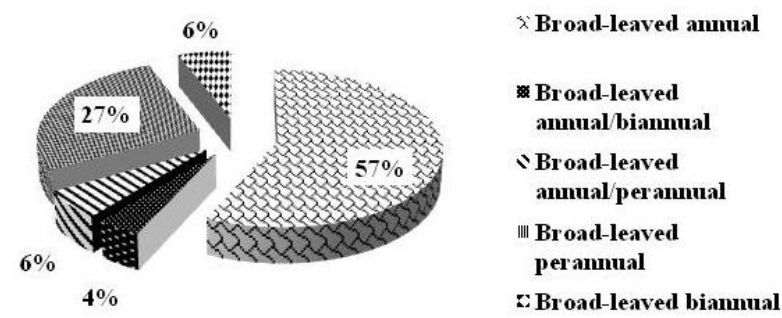

Figure 6 Relative frequencies of broad leaved weeds in terms of life span

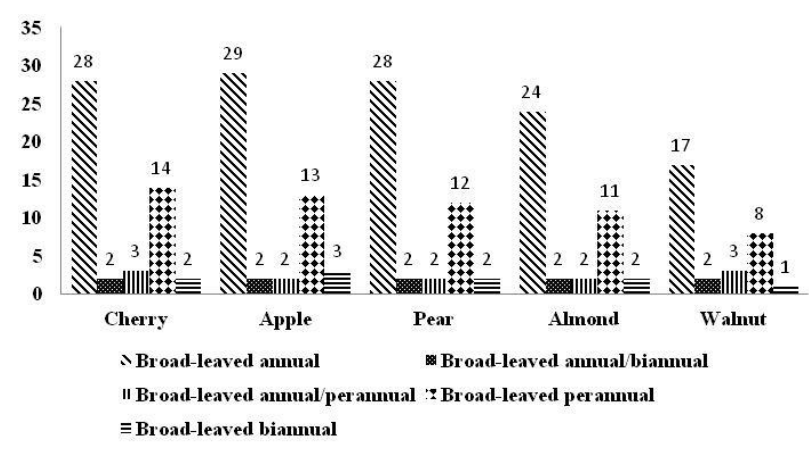

Figure 7 The number of broad leaved weed species in each fruit tree in terms of life span

The highest weed density was noted for A. retroflexus and $C$. album, with 76.00 and 54 plant $/ \mathrm{m}^{2}$, respectively. The other dense weeds were Datura stramonium, Euphorbia helioscopia, P. oleracea and Lactuca serriola with 24, 22, 21 and 20 plants $/ \mathrm{m}^{2}$ (Figure 3). The density of $D$. stramonium (21 plant $\left./ \mathrm{m}^{2}\right)$ and A. retroflexus $\left(52 \mathrm{plant} / \mathrm{m}^{2}\right)$ was higher in walnut orchards, Artemisia absinthium (21 plant $/ \mathrm{m}^{2}$ ) was predominant in apple growing areas, $P$. oleraceae and $C$. album was predominant in almond and pear plantations.
Among broad leaved species one species was parasitic weed. European misletoe Viscum album was observed on almond, cherry and pear trees. Compared to apple the intensity of dodder infection was higher in cherry trees. Widespread distribution of this weed in Tekirdağ Province Malkara and Süleymanpaşa districts, Edirne Province Keşan district and Kırklareli Province Merkez district was observed. The number of parasitized fruit trees was counted as 77 in Kizılcıkdere Village of Kirklareli. The higher distribution of this weed is considered to be due to abundant presence of pollinator insects and vector birds.

Additionaly to misletoe another parasitic weed dodder Cuscuta campetris Yunck was found attached to newly emerged apple scions and cherry rootstocks (Figure 5). This parasite was detected in two locations in Tekirdağ. Cherry rootstocks were heavily parasitized in infested orchard. (Figure 5). Dodder are a group of over 150 species in the genus Cuscuta (McNeal et al., 2007). Dodder is a parasitic annual that relies on its host for survival. These species have a wide variety of host plants and in our survey C. campestris was seen attached to young apple scions and cherry rootstocks.

The rest of weeds weeds were narrow leaved monocotyledons. These resemble long grasses with parallel veins and round stems. Bromus tectorum, Agropyron repens, Alopecurus myosuroides, Poa annua, Sorghum halepense, Echinochloa crus-galli, Setaria viridis, Cynodon dactylon, Avena fatua, Eleusine indica., Lolium perenne are grass from Poaceae and Cyperus rotundus from Cyperaceae family were recorded in orchards in Northwestern Marmara. These narrow leaved monocotyledons bloom at different periods, some flowering in winter and some in summer (Table 4).

As regard to life span recorded weeds classified in five groups: Annuals, biannuals, perannuals and some with both annual/biannual and annual/perarnnual characteristics. Among 64 species 39 were annuals, 16 were perennials, 3 species were biannual, 2 species were annual/biannual and 4 species were annual/per annual (Figure 4, Figure 5). The majority of broad leaved dicotyledons were annual weeds (Figure 6, Figure 7).

Based on our records more than half of monocotyledons were annual weeds (Figure 8). Walnut orchards contain all narrow leaved weeds while Lolium perenne per annual weed was not present in cherry, apple, pear and almond orchards (Figure 9).

Life form analysis of weed flora in Northwestern Marmara showed dominant presence of therophytes (38 species) whereas hemicryptophytes were recorded the second most frequent life form (20 species) following Geophytes (3 species) Chamaephytes (2 species) and Phanerophyte (1 species) (Figure 10). Most of the species in apple, cherry, almond and walnut trees were therophytes (Table 5).

Most of the weeds in surveyed areas belong to the cosmopolitan floristic element, followed by Eur-Asian+ North African (Table 6). The others were Mediterranean, North Africa, South America and North America which has only one species.

Some of the recorded weeds in our study including Solanum nigrum, Sorghum halepense and Taraxacum officinale are known as alternate host of several nematode species, pathogens, many viral diseases including Raspberry Ringspot Nepovirus, Cherry Raspleaf Virus, 
Tomato Ringspot Virus and Tobacco Ringspot Nepovirus (Hansen et al., 1974; Holm et al.,1977; Holm et al., 1991; Mountain et al., 1992). These weeds are also main hosts of several aphids and moths (Landolt, 2002).
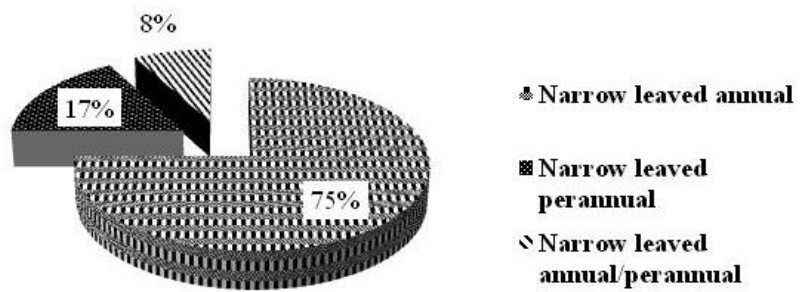

Figure 8 Relative frequencies of narrow leaved left weeds in terms of life span

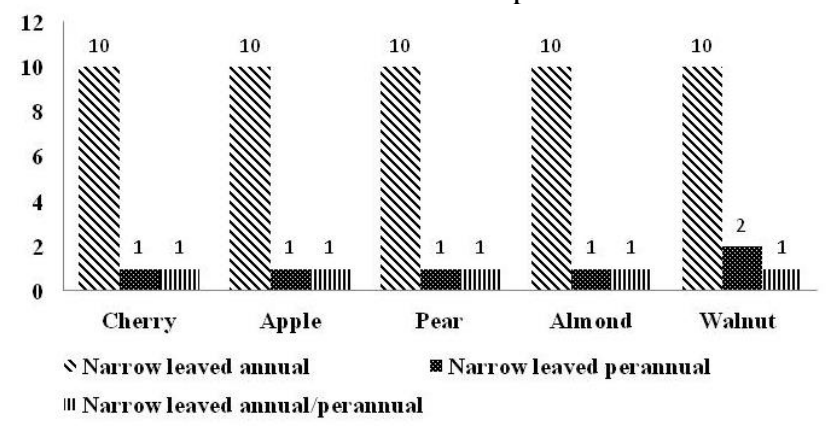

Figure 9 The number of narrow leaved weed species in each fruit tree in terms of life span

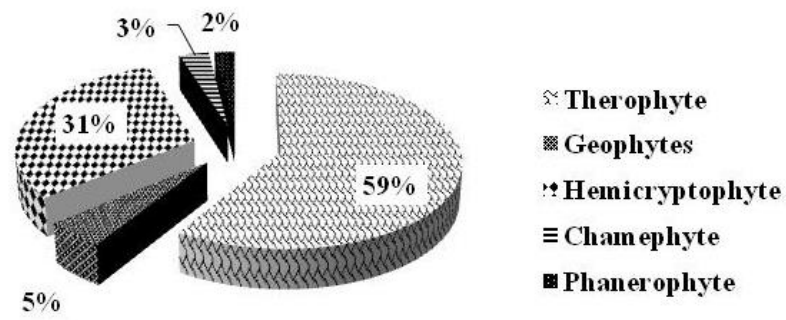

Figure 10 Life form percentages recorded in the study area

\section{Conclusion}

This study provide the information on recent weed flora of Northwestern Marmara Region of Turkey. The weed flora constitute 64 species of which some were reported important competitors. Within 64 species 39 were annuals, 16 were perennials, 3 species were biannual, 2 species were annual/biannual and 4 species were annual/per annual. The weed flora of orchards has not been studied and our findings will promote for further studies to solve weed problems.

\section{References}

Eşitmez B, Işık D, 2016. Kayseri İli Elma Bahçelerinde Görülen Yabancı Ot Türlerinin Belirlenmesi, Meyve Bilimi Dergisi, cilt.3, ss.1-9

Hansen AJ, Nylland G, McElroy FD, Stace-Smith R, 1974. Origin, cause, host range and spread of Cherry Rasp Leaf disease in North America. Phytopathology 64, 721-727.

Holm LG, Donald P, Pancho JV, Herberger JP, 1977. The World's Worst Weeds: Distribution and Biology. The University Press of Hawaii, Honolulu, Hawaii. 609 pp

Holm LG, Pancho JV, Herberger JP, Plucknett DL, 1991. A Geographic Atlas of World Weeds. Malabar, Florida, USA: Krieger Publishing Company.

Holm L, Doll J, Holm E, Pancho J, Herberger J, 1997. World Weeds: Natural Histories and Distribution.John Wiley, New York.

Korsmo E, Torstein V, Fykse H, 1981. Korsmos' Ugras Plansjer. Oslo, Norway: Norsk Landbruk/Landbruks Forlaget.

Landolt PJ, 2002. Survival and development of Lacanobia subjuncta (Grote \& Robinson) (Lepidoptera: Noctuidae) larvae on common weeds and crop plants of Eastern Washington state. Pan-Pacific Entomologist, 78(1):1-6; 8 ref.

McNeal JR, Arumugunathan K, Kuehl JV, Boore JL, 2007. Systematics and plastid genome evolution of the cryptically photosynthetic parasitic plant genus Cuscuta (Convolvulaceae) BMC Biol. 2007;5:1.

Mountain WL, Powell CA, Forer LB, 1992. A trough system for measuring transmission of Tomato Ringspot Virus by dagger nematodes. HortScience, 27(12):1283-1285

Nasr N, Hajar B, Miyandeh BH, 2013. Weeds identification in west of Mazandaran Province Citrus Orchards (Iran). American Journal of Research Communication, 1(6):27-38

Ozer Z, Kadioglu I, Onen H, Tursun N, 1998. Herboloji (Yabanc1 Ot Bilimi), Genişletilmiş 2. Bask1. Gaziosmanpaşa Üniversitesi, Ziraat Fakültesi Yayınları No:20, Kitaplar Serisi No: 10, 403s., Tokat.

Sırma M, Kadığlu İ, Yanar Y, 2001. Tokat İli Domates Ekim Alanlarında Saptanan Yabancı Ot Türleri, Yoğunlukları ve Rastlanma Sıklıkları. Türkiye III. Herboloji Kongresi Bildiri Özetleri, Ankara.

Stevens O, 1957. Weights of seeds and numbers per plant. Weeds, 5:46-55.

Tesio F, Ferrero A, 2010. Allelopathy, a chance for sustainable weed management. International Journal of Sustainable Development \& World Ecology, 17:5, 377-389

Walsh RA, 1993. Amaranthus retroflexus. In: Fire Effects Information System, U.S. Department of Agriculture, Forest Service, Rocky Mountain Research Station, Fire Sciences Laboratory.

Wisler GC, Norris RF, 2005. Interactions between weeds and cultivated plants as related to management of plant pathogens. Sym. Weed Sci. 53:914-917.

Witt A, Luke Q, 2017. Guide to the naturalized and invasive plants of Eastern Africa, [ed. by Witt, A., Luke, Q.]. Wallingford, UK: CABI.vi + $601 \mathrm{pp}$.

Yazlık, A. and Tepe, I., 2001. Van ve yöresinde elma ve armut bahçelerindeki yabancı otlar ve dağılışları üzerinde araştırmalar. Türkiye Herboloji Derg., 4 (1): 11-20. 